\title{
Development of High Order Thinking Skills Based Assessment Tools in Pancasila Course: Critical Digital Citizenship Oriented
}

\author{
Triyani, Maryam Mustika, Sakman, Herry B Mantir \\ Fakultas Keguruan dan Ilmu Pendidikan, Universitas Palangka Raya, Indonesia \\ triyani@fkip.upr.ac.id,maryammustika@fkip.upr.ac.id,sakman@fkip.upr.ac.id, \\ herrymantir@fkip.upr.ac.id
}

DOI: $10.20884 / 1 . j 1 i .2021 .12 .2 .4942$

\begin{abstract}
Article History:
First Received:

$21 / 10 / 2021$

ABSTRACT

The purpose of this research and development is to develop a HOTS-based assessment tool oriented to critical digital citizenship on Pancasila as an

Final Revision:

$13 / 12 / 2021$ ethical system and Pancasila as the basis for developing science and technology, namely the production of an assessment tool that focuses on higher-order thinking skills (HOTS) in students. The method used in this research is the type of development research $(R \& D)$ with stages of market

Available online: needs analysis, development, testing, and product revision. The form of the

$31 / 12 / 2021$ implementation of this research can be described as (1) workshop on analysis of Pancasila course curriculum (learning outcomes, material substance, assessment tools that have been developed; (2) workshop on development of HOTS-based assessment tools in Pancasila courses oriented towards critical digital citizenship ; (3) FGD expert validation; (4) trial of HOTSbased assessment tool in Pancasila course is oriented towards critical digital citizenship; and (5) preparation of the final research report. The results of this research and development that is based on expert assessment (expert) to the assessment tool were developed which got a mean score of 3.6 in both categories so that used for the assessment process. Based on the results of trials and reflections on the HOTS-based assessment tool oriented to critical digital citizenship, it was found that, First, students are happier when learning uses audio-visual. Second, the learning video assessment tool makes them better understand in analyzing phenomena that occur in society related to the actualization of Pancasila values in their daily lives and environment. Third, the questions contained in the video make students think critically. Fourth, this learning video makes students understand and realize that there are still many students ignorant in their actions to be able to apply the values of Pancasila.
\end{abstract}

Keywords: assessment; HOTS; critical digital citizenship

\section{INTRODUCTION}

The assessment process cannot be separated from a series of learning processes. Assessment in the learning process can be used as a basis for improving the learning process and vice versa the learning process can be used as a basis for conducting the assessment process. Assessment is used to assess whether the process of developing student thinking has been running properly and 
whether educational goals have been achieved with the programs and activities that have been carried out (Widodo, 2010).

Graduates who are expected from lectures at universities are graduates who have high-level thinking skills in a critical sense of environmental issues. Heong et al (2011), explained that higherorder thinking skills "it requires someone to apply new information or prior knowledge and manipulate the information to reach possible answers in new situation". This has the meaning that higher-order thinking skills require a person to apply new information or prior knowledge and manipulate information to reach possible answers in different conditions. High order thinking skills is a thinking ability at a higher level, in the sense that it is not limited to memorization and memory, but rather on the aspects of analysis, assessment, and creation (Bloom, 1956; Anderson, 2001; Gunawan, 2012).

Higher-order thinking skills receive special attention from one of the international study institutions that examine the low cognitive ability of Indonesian human resources. For a student, higher-order thinking skills can be cultivated through learning activities. The form of learning activities that can provide experiences for students to think at a higher level is to provide problembased learning experiences or problem based learning or contextual learning that is contextual teaching and learning. As with learning activities in general, after learning is carried out, an assessment is carried out to determine the level of success to achieve learning objectives. According to Hosnan (2014), the assessment is carried out to collect information related to student learning progress following the competencies that must be mastered. Referring to the low ability of students to perform higher-order thinking skills, there is a need to develop an assessment instrument that is oriented towards measuring higher-order thinking skills. Qualified graduates are graduates who have high-level critical thinking skills or better known as higher order thinking skills (HOTS) so that education in the 21 st century must contain assessment tools or questions that can train HOTS abilities. Students are new citizens and are the main users of digital technology (Mukminan, 2015; Kodriana, 2017; Fitriani, 20018; Rahmah, 2019; Subay, 2020).

According to Osborne and Millar (in Avargil, 2011), explaining that "in the past, a most common way of assessing students was the traditional form of summative test. This sort of test usually examined content knowledge and did not assess higher-order thinking skills". This means that in the past the assessment of students was done traditionally, namely through summative tests. This type of question does not assess the students' knowledgeability in higher-order thinking. To develop students' critical thinking skills, one of the things that can be done is to be bridged with assessment innovations that are following the times, namely the digital world. Students are 
required to be critical and can identify, access, manage, integrate, evaluate, analyze and synthesize digital resources. So that digital literacy can be understood in three aspects, namely digital competence, digital use, and digital transformation (Chan, 2014). With these capabilities, which are packaged in the form of digital-based assessment, it is hoped that they will be able to realize critical digital citizenship. The learning assessment activity used to bridge the realization of critical digital citizenship is to provide an assessment of problem-based learning or problem based learning or contextual learning that is contextual teaching and learning. Therefore, based on the explanation above, the researchers conducted research related to the development of HOTSbased assessment tools in Pancasila courses oriented to critical digital citizenship".

\section{MATERIALS AND METHOD}

The method used in this research is the type of development research $(R \& D)$ with stages of market needs analysis, development, testing, and product revision. The product that will be developed in this research is a HOTS-based assessment tool in the Pancasila course, which is oriented towards critical digital citizenship. The details of the program in this research activity consist of:

1. Analysis of subject learning achievement for Pancasila courses.

2. Depth analysis of the substance of the Pancasila course material

3. Analysis of assessment tool materials with problem analysis (case studies), problem-solving in Pancasila courses.

4. The development of a HOTS-based assessment tool in the Pancasila course is oriented towards critical digital citizenship.

5. The trial of the HOTS-based assessment tool is oriented towards critical digital citizenship in the Pancasila course.

6. The revision of the HOTS-based assessment tool is oriented towards critical digital citizenship in the Pancasila course.

7. The prototype of the HOTS-based assessment tool draft is oriented towards critical digital citizenship in the Pancasila course.

The form of the implementation of this research can be described as follows.

1. Workshop on Pancasila course curriculum analysis (learning outcomes, material substance, assessment tools that have been developed) 
Analysis of the course curriculum is necessary because it must look at the learning outcomes, the depth of the substance of the material, and the assessment tools that already exist in the Pancasila course.

2. Workshop on the development of HOTS-based assessment tools oriented to critical digital citizenship in the Pancasila course

So far, there are many assessment tools available for Pancasila courses, but these assessment tools are not based on HOTS which develops students' cognitive competencies from C4 (analysis), C5 (assessment), and C6 (create/creativity). The development of a HOTS-based assessment tool oriented to critical digital citizenship requires an in-depth study of the substance of the material and the problems that occur related to the material being developed so that this research is needed to produce a prototype draft of a HOTS-based assessment tool in the Pancasila course.

3. FGD expert validation HOTS-based assessment tool oriented to critical digital citizenship in Pancasila course

Expert validation (expert judgment) from an expert or assessment expert is needed to validate the assessment tool so that it meets the validation criteria which later on the question can be used by all the same criteria.

4. Trial and reflection of HOTS-based assessment tool oriented to critical digital citizenship in Pancasila course

The trial of the HOTS-based assessment tool in the Pancasila course in a limited class was carried out in a small class (one study program) of students taking Pancasila courses. The test results are processed to obtain field validation of the assessment tool that has been developed.

\section{RESULTS \& DISCUSSION}

The description of the research and development data is described based on the stages of research and development of the developed assessment instrument. The description of the data presented is based on the results of each stage of the research and development process which includes: analysis of learning outcomes for Pancasila courses, especially Pancasila as an ethical system and Pancasila as the basis for science and technology development; developing HOTS - 
based assessment tools, testing assessment tools and revising the results of testing assessment tools.

First, the workshop on analysis of the curriculum analysis of Pancasila education courses, especially the material of Pancasila as an ethics system and Pancasila as the Basis for the Development of Science and Technology was carried out because it saw several problems in the field, namely, there was a tendency to learn Pancasila Education material and the assessment carried out more emphasized aspects of student knowledge and was still theoretical. normative and emphasizes the ability to memorize as well as in evaluating. This raises a dilemma because the main orientation of the Pancasila Education course is to develop the character of students following the noble values of the Indonesian nation and form the character of good citizens. Therefore, efforts are needed on how to package the material and assessment of Civic Education learning to suit the needs of students and the times. The results of the workshop in the form of citizenship course curriculum analysis (learning outcomes, material substance, assessment tool) resulted in curriculum and material mapping as well as an assessment of what was planned regarding the results of the learning outcomes analysis on Pancasila as an ethical system and Pancasila as the basis for science and technology development.

Second, workshop on development of HOTS-based assessment tools in Pancasila Education courses with material Pancasila as an ethical system and Pancasila as the basis for developing science and technology. The availability of the assessment tool is not based on HOTS which develops students' cognitive competencies from C4 (analysis), C5 (assessment), and C6 (create/creativity). Problem-based assessment or HOTS-based assessment (high order thinking skills) is shown to train students to think critically and put more emphasis on students for highorder thinking or high order thinking skills (HOTS). With the development of students' ability to think at a higher level, they are expected to be able to respond to factual problems that occur in society. To collect various cases or factual problems that occur in the community which is then harmonized with the substance of the material that has been prepared, namely Pancasila Education.

Third, FGD expert validation of HOTS-based assessment tools in Pancasila Education Courses, especially Pancasila as an ethical system and Pancasila as the basis for science and technology development. Expert validation (expert judgment) from an expert or assessment expert is needed to validate the assessment tool so that it meets the validation criteria which later on the question can be used by all the same criteria. The following are the results of the expert's assessment of the assessment tool that the team has developed. 
Table 1. Results of Expert Assessment Tools Based on HOTS Oriented on Critical Digital Citizenship

\begin{tabular}{lllc}
\hline No. & Name & \multicolumn{1}{c}{$\begin{array}{c}\text { Position/Work } \\
\text { Unit/Agency }\end{array}$} & $\begin{array}{c}\text { Average } \\
\text { Score }\end{array}$ \\
\hline $1 . \quad$ Expert Judgment & Lecturer & 8.75 \\
\hline & Average & 8.75 \\
\hline
\end{tabular}

Based on Table 1, the assessment of learning assessment experts with the selfassessment principle shows that the assessment prototype based on the self-assessment principle is good. Referring to the expert assessment, it can be concluded that the assessment prototype for Pancasila Education learning materials is suitable for use with revisions according to expert input in the citizenship lecture process. In addition, from the expert judgment assessment, there are several inputs for improving the assessment, namely, it is necessary to add questions related to solutions to overcome factual problems that are contrary to the values of Pancasila and to further strengthen the objectives of critical digital citizenship, it is necessary to have a solution offered by students to each case presented.

Fourth, testing the HOTS-based assessment tool in the Pancasila Education Course. Development research requires an implementation stage to practically evaluate the extent to which the indicators of the success of the product developed can be achieved. In addition, the activity implementation team needs to carry out lecture reflection activities. In this reflection, the implementing team distributed several student assessment instruments for the assessment tools developed. Based on the reflection of the test results on the aspects of weaknesses, strengths, and suggestions, it shows that broadly speaking, the questions can be understood and worked on, but some questions cannot be understood, because language is difficult to understand. The trial was carried out in the Building Engineering Education Study Program and the Animal Husbandry Department with a total of 50 students.

Based on the results of testing the assessment tools that have been developed, it can be analyzed that most of the students succeeded in answering even though they had different levels of analytical skills. From the questions offered, students have been able to analyze problems related to ethics and abuse of science and technology advancements that are not following the values of Pancasila. Students have been able to build arguments, especially in terms of providing solutions to the problems presented by the research team through question instruments. 
Based on the results of trials and reflections of the HOTS-based assessment tool oriented to critical digital citizenship, it is obtained that, First, students are happier when learning uses audio-visual so that they are interested in attending lectures. Second, the learning video assessment tool makes them better understand in analyzing phenomena that occur in society related to the actualization of Pancasila values in their daily lives and environment. Third, the questions contained in the video make students think critically. Fourth, this learning video makes students understand and realize that there is still many students' ignorance in their actions to be able to apply the values of Pancasila.

Assessment instruments in the form of questions HOTS is a measurement instrument used to measure the ability to think critically, the ability to think that not only recall (recall), restate (restate), or refer without processing (recite). HOTS questions in the context of an assessment measure the ability to (1) transfer one concept to another, (2) process and apply information, (3) find connections from different kinds of information, (4) use information to solve problems, and (5) examine ideas and information critically. However, HOTS-based questions do not mean more difficult questions than recall questions. In writing HOTS questions, various test instruments should be used. Sugrue (1994) suggests that "formats for measuring higher-order thinking skills: (1) selection (multiple-choice, matching), (2) generation (short answer, essay, performance), and (3) explanation (giving reasons for selection). or generation of a response". In the preparation of HOTS questions generally use a stimulus. Stimulus is the basis for making questions. In the context of HOTS, the stimulus presented should be contextual and interesting. The stimulus can be sourced from global issues such as information technology problems, science, economics, health, education, and infrastructure. The stimulus can also be raised from problems that exist in the environment around the education unit such as culture, customs, cases in the region, or various advantages found in certain areas.

Critical thinking skills provide benefits to students, especially at the student level, to analyze and conclude behaviors and actions both in daily life and in cyberspace that cannot be separated from the current grip, especially in communicating with other people, whether with applicable rules or not and back again. to the application of Pancasila values as a form of a good citizen. Students are new citizens and become the main users of digital technology. In this case, students need to prepare themselves to participate in public spaces that are different from conventional ones. The Pancasila course is one of the courses that have the responsibility to prepare millennial citizens to participate in creating civilized democracy with digital citizenship (digital citizenship). 


\section{CONCLUSION}

Assessment is an important and inseparable part of the learning process and even becomes an important stage in the learning process. To get good assessment results, a good assessment tool is needed as well. It is hoped that the assessment tool is not only limited to developing the ability to memorize and remember but more to the ability to analyze and synthesize. For this reason, it is necessary to develop an assessment tool that can measure the achievement of the learning objectives. The purpose of this study is to develop an assessment tool based on HOTS (high order thinking skills) oriented to critical digital citizenship on Pancasila as an ethical system and Pancasila as the basis for science and technology development. The results of the research on developing a HOTS-based assessment tool are oriented towards critical digital citizenship, namely a valid and appropriate assessment tool for use in the learning process of Pancasila Education in universities. This is based on expert judgment and the results of input and suggestions from students.

\section{ACKNOWLEDGEMENT}

The authors would like to thank the Teacher Training and Education Faculty of Palangka Raya University for funding this research program.

\section{REFERENCES}

Anderson, L.W., \& Krathwohl, D.R. (2001). A Taxonomy for Learning, Teaching, and Assessing: A Revision of Bloom's Taxonomy of Educational Objectives. New York: Addison Wesley Longman, Inc.

Avargil, S. Herscovitz, O. \& Dori, Y. J. (2012). Teaching Thinking Skills In Context-Based Learning: Teachers' Challenges and Assessment Knowledge. Journal: Science Education Technology.

Bloom, B.S., Engelhart, M.D., Furst, E.J., Hill, W.H., dan Krathwohl, D.R. (1956). The Taxonomy of Educational Objectives The Classification of Educational Goals, Handbook I: Cognitive Domain. New York: David McKay.

Chan, C., Lei, W., \& Lena, X. (2014). A Study of Video Effects on English Listening Comprehension. Studies in Literature and Language, 8(2), 53-58. https://doi.org/10.3968/4348.

Fitriani, D., Suryana, Y., \& Hamdu, G. (2018). Pengembangan Instrumen Tes Higher-Order Thinking Skill pada Pembelajaran Tematik Berbasis Outdoor Learning di Sekolah Dasar Kelas IV. Indonesian Journal of Primary Education, 2(1), 87-96. https://doi.org/10.17509/ijpe.v2i1.13752. 
Gunawan, I; Palupi, Retno Anggarini. 2012. Taksonomi Bloom-Revisi Ranah Kognitif: Kerangka Landasan Untuk Pembelajaran, Pengajaran, Dan Penilaian. Premere Educandum Jurnal Pendidikan Dasar Dan Pembelajaran Volume 2 Nomor 2.

Heong, y. et.al. (2011). The Level Marzano Higher Order Thinking Skills Among Technical Education Students.Journal: International of Social Science and Humanity.

Hosnan, M. (2014). Pendekatan Saintifik Dan Konstektual Dalam Pembelajaran Abad 21: Kunci Sukses Implementasi Kurikulum 2013.Bogor: Penerbit Ghalia Indonesia.

Kodriana, W., Mulyana, E. H., \& Nugraha, A. (2017). Pengembangan Soal Tes Berbasis HOTS pada Outdoor Learning di Sekolah Dasar. PEDADIDAKTIKA: Jurnal Ilmiah Pendidikan Guru Sekolah Dasar, 4(1), 61- 72.

Mukminan. (2015). Kurikulum Masa Depan. Universitas Sultan Ageng Tirtayasa, Banten, Indonesia.

Rahmah, A. N., \& Muharni, L. P. J. (2019). Identifikasi Soal Tipe Higher Order Thinking Skills (HOTS) Pada Buku Matematika Materi Persamaan dan Pertidaksamaan Linear Satu Variabel. Edu Math Journal Prodi Pendidikan Matematika, 7(1), 1-8.

Subay, R. (2020). Pengembangan Assessment Tes Higher Order Thinking Skills (Hots) Peserta Didik Pada Pembelajaran Matematika Kelas Vii Berbasis Model Rasch. Tesis. Universitas Negeri Semarang: Prodi Penelitian dan Evaluasi Pendidikan.

Sugrue, B. (1995). A theory-based framework for assessing domain-specific problem-solving ability. Educational Measurement: Issues and Practices, 14(3), 29-36.

Widodo. (2010). Analisis Butir Soal Tes. Jurnal Pendidikan Penabur No. 14/Tahun ke-9/ Juni 2010 SDK BPK Penabur. Diakses tanggal 4 Oktober 2020. 